\title{
HNF $1 \propto$ Mutations Are Present in Half of Clinically Defined MODY Patients in South-Brazilian Individuals
}

clinical case report

\author{
JORGE DE FARIA MARASCHIN \\ CAROLINE KANNENGIESSER \\ NÁDIA MURUSSI \\ Nicole Campagnolo \\ LUÍs HeNRIQUe Canani \\ JORGE LUIZ GROSS \\ GILBERTo VeLHo \\ BERNARD GRANDCHAMP \\ SANDRA PINHO SILVEIRO
}

\begin{abstract}
Maturity-onset diabetes of the young (MODY) is a monogenic form of diabetes mellitus characterized by autosomal dominant inheritance, early age of onset, and pancreatic beta cell dysfunction. Heterozygous mutations in at least seven genes can cause MODY. In the present study we investigated the relative prevalence of GCK (glucokinase) and HNF1 (hepatocyte nuclear factor $1 \alpha$ ) mutations, the more frequent causes of MODY, in 13 South-Brazilian families with multiple cases of diabetes consistent with MODY. Heterozygous variants in GCK and HNF1 $\alpha$ genes were observed respectively in one $(7.7 \%)$, and six (46.2\%) families. The six HNF1 $\alpha$ variants are likely to cause diabetes in the families where they were observed. However, we could not ascertain whether the GCK Gly117Ser variant found in one family is a causal mutation. In conclusion, we have confirmed in a South-Brazilian population that HNF1 $\alpha$ mutations are a common cause of monogenic diabetes in adults selected with strict clinical diagnostic criteria. (Arq Bras Endocrinol Metab 2008; 52/8: 1326-1331)
\end{abstract}

Keywords: Maturity-onset diabetes of the young; Monogenic diabetes; Transcription factor; Glucokinase; Hepatocyte Nuclear Factor $1 \alpha$

\section{RESUMO}

Mutações HNF1 $\alpha$ Estão Presentes na Metade dos Pacientes da Região Sul do Brasil Clinicamente Diagnosticados com MODY.

O maturity-onset diabetes of the young (MODY) é uma forma monogênica de diabetes melito caracterizada por herança autossômica dominante, de instalação precoce, como disfunção da célula beta pancreática. Mutações heterozigotas em pelo menos sete genes causam MODY. No presente estudo, investigamos a prevalência relativa das mutações da GCK (glucokinase) e HNF1 $\alpha$ (hepatocyte nuclear factor $1 \alpha$ ), as causas mais freqüentes de MODY, em 13 famílias sul-brasileiras com múltiplos casos de diabetes consistentes com MODY. Variantes heterozigotas nos genes da GCK e HNF1 $\alpha$ foram observadas, respectivamente, em uma $(7,7 \%)$ e em seis $(46,2 \%)$ famílias. As seis variantes do HNF1 $\alpha$ provavelmente causaram o diabetes nas famílias nas quais foram observadas. No entanto, não se pode afirmar que a variante GCK Gly117Ser encontrada em uma família seja a mutação causal. Em conclusão, confirmamos que, em uma população do sul do Brasil, as mutações $H N F 1 \alpha$ são uma causa comum de diabetes monogênico em adultos selecionados com critérios clínicos diagnósticos estritos. (Arq Bras Endocrinol Metab 2008; 52/8:1326-1331)

Keywords: Maturity-onset diabetes of the young; Diabetes monogênico; Fator de transcrição; Glucoquinase
Received in $1 / 9 / 2008$

Accepted in 23/10/2008 


\section{INTRODUCTION}

aturity-onset diabetes of the young (MODY) is a monogenic form of diabetes mellitus characterized by autosomal dominant inheritance, early age of onset (usually before 25 years of age), and pancreatic beta cell dysfunction (1-3).

MODY is not a single entity, but presents genetic as well as metabolic and clinical heterogeneity. Heterozygous mutations in at least seven genes cause MODY $(1,4)$. These genes encode the enzyme glucokinase (GCK: MODY2), the transcription factors Hepatocyte Nuclear Factor $4 \alpha$ (HNF4a: MODYl), Hepatocyte Nuclear Factor $1 \alpha$ (HNF1 1 : MODY3), pancreatic and duodenal homeobox 1 gene (PDXl: MODY4), Hepatocyte Nuclear Factor 1 beta (HNF1 $\beta$ or TCF2: MODY5) neurogenic differentiation l (NEURODI) and the insulin gene (INS).

MODY2 and MODY3 subtypes may account for up to $70 \%$ of cases of MODY in series with strictly defined phenotype (5-7) and MODYl, when tested, might represent a few percent of the cases (8). MODY5 is now recognized to be a multisystemic disorder, with a much wider and heterogeneous clinical spectrum that often does not include diabetes $(9,10)$. Other MODY sub-types are rare disorders, described only in a few families while the prevalence of additional unidentified locus or loci (MODY-X) remains unclear.

The aim of the present study was to investigate the relative prevalence of $G C K$ and $H N F l \alpha$ mutations in a collection of South-Brazilian families with multiple cases of diabetes consistent clinically with MODY, and to describe their clinical and metabolic profile.

\section{SUBJECTS AND METHODS}

Probands of thirteen families were studied. These subjects were identified in the adult outpatient clinics and Diabetes Department of Hospital de Clínicas de Porto Alegre, Federal University of Rio Grande do Sul (UFRGS), Porto Alegre, Brazil. All subjects had overt diabetes and a family history of diabetes in at least two consecutive generations ( $80 \%$ in three generations), with diabetes diagnosed before the age of 25 in at least one individual, and negative pancreatic antibodies. Four additional members of three families were also studied. The research protocol was approved by the local ethics committee, and all patients signed an informed consent form.

\section{Patient evaluation}

Patients underwent a standardized evaluation consisting of a questionnaire, physical examination, and laboratory tests. Weight without shoes and in light outdoor clothes and height were measured and body mass index (BMI) was calculated. Measurements of waist circumference at the narrowest point as viewed from the front were performed. Hypertension was defined using the mean of two office blood pressure measurements $\geq 140 / 90$ $\mathrm{mmHg}$ or by the use of antihypertensive medication. An ophthalmologist performed direct fundoscopy, and the presence of diabetic retinopathy was classified as absent, non-proliferative, or proliferative. Patients were classified into normoalbuminuric (urinary albumin excretion [UAE] $<30 \mathrm{mg} / 24 \mathrm{~h}$ ), microalbuminuric (UAE 30-300 $\mathrm{mg} / 24 \mathrm{~h}$ ), or macroalbuminuric (UAE $\geq 300 \mathrm{mg} / 24 \mathrm{~h}$ ), based on 24-h sterile urine collections, confirmed in two out of three samples. Ischemic heart disease was established in the presence of angina or possible infarct according to the World Health Organization Cardiovascular Questionnaire and/or the presence of resting electrocardiogram abnormalities. Neurological tests were performed to evaluate sensation, deep reflexes, and strength.

\section{Laboratory methods}

UAE was measured by immunoturbidimetry (Microalb; Ames-Bayer, Tarrytown, NY; intra- and interassay coefficients variation of 4.5 and $11.0 \%$, respectively). HbAlc was measured by a high-performance liquid chromatography system (normal range 4-6\%; MerckHitachi 9100). Fasting plasma glucose was measured by the glucose-peroxidase colorimetric enzymatic method (Biodiagnóstica). Creatinine was measured by the Jaffé method and the lipid profile by a colorimetric method. Serum C-peptide was measured by chemiluminescence, glutamic acid decarboxylase (GAD) antibody by radioimmunoassay (11).

\section{Molecular analysis}

The promoter, the coding regions and intron-exon junctions of GCK and HNFla were screened for mutations by direct sequencing.

\section{Statistical analysis}

Student's t test or $\chi^{2}$ tests were used to compare clinical and laboratorial data. Data are expressed as the means \pm SD. Variables without normal distribution were expressed as median (range) and were log-transformed for statistical tests. P values $<0.05$ (two tailed) were considered to be significant. 


\section{RESULTS}

Thirteen families with clinically defined MODY were screened (Figure 1). Heterozygous variants in glucokinase and HNFla genes were observed, respectively, in one $(7.7 \%)$ and six $(46.2 \%)$ families (Table 1). A c. $349 \mathrm{G}>\mathrm{A}$ variant in exon 3 of the glucokinase gene that results in the replacement of a glycine by a serine at codon 117 (p.Glyl17Ser) was observed in the proband from kindred FER, but was not present in the proband's elder sister who also had diabetes. No other $G C K$ variant was observed in these families.

Table 1. Allelic variations in MODY genes.

\begin{tabular}{|c|c|c|c|c|}
\hline Gene & Location & Nucleotide change & Protein change & Kindred \\
\hline GCK & Exon 3 & c. $349 G>A$ & p.Gly 117Ser & FER \\
\hline $\mathrm{HNFl} \alpha$ & Exon 1 & c.24_35dup12 & p.Gln9_Leu12dup & MIL \\
\hline $\mathrm{HNFl} \alpha$ & Exon 1 & c. $92 G>A$ & p.Gly31Asp & RIB \\
\hline $\mathrm{HNFl} \alpha$ & Exon 3 & c.638T>C & p.lle213Thr & TEM \\
\hline $\mathrm{HNFl} \alpha$ & Exon 4 & c.872_873insC & p.Gly292Arg fsX24 & TRI \\
\hline $\mathrm{HNFl} \alpha$ & Exon 6 & c.1136_1137 delCT & p.Pro379Arg fsX37 & GRU \\
\hline $\mathrm{HNFl} \alpha$ & intron 7 & c. $1501+1 G>T$ & unknown & VIE \\
\hline
\end{tabular}

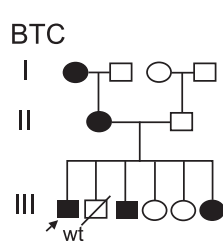

FERN

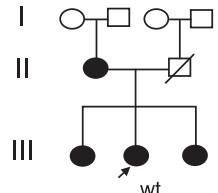

GRU
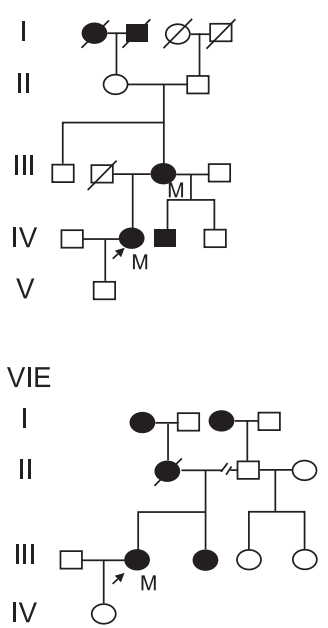

SIL

I

II

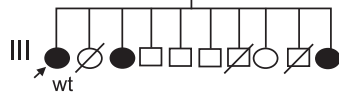

FER

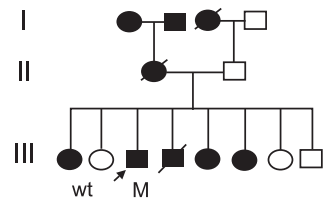

RIB

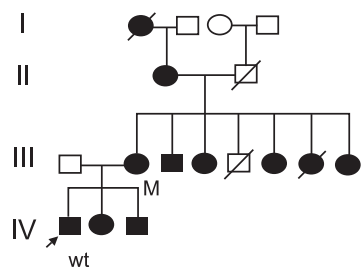

ROS

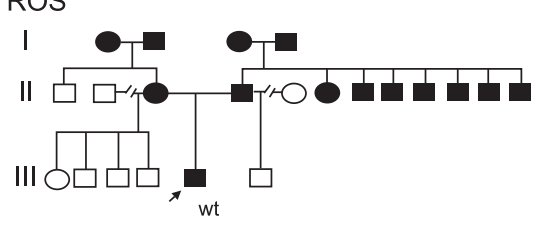

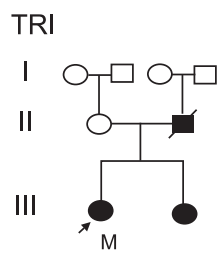

TEM

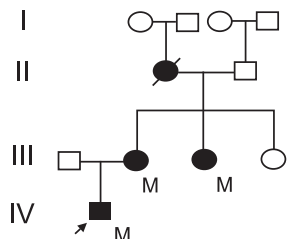

MIL

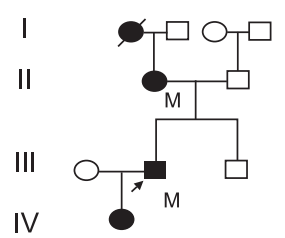

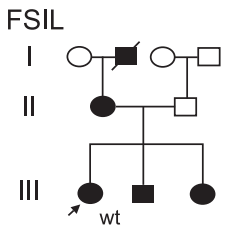

ROC

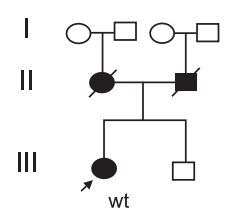

Figure 1. Pedigrees of the 13 families. Arrows identify the probands. Squares denote male family members, and circles denote female family members. W† stand for wild type and M for mutant alleles of glucokinase or HNF- $1 \alpha$ genes. 
A duplication of 12 nucleotides (c.24_35dupl2: GCAGACGGAGCT) in exon 1 of HNFl $\alpha$ resulting in the duplication of four aminoacids (Gln, Thr, Glu, Leu) was observed in the proband from kindred MIL as well as in his diabetic mother. Two missense variants were also observed. A c. $92 \mathrm{G}>\mathrm{A}$ variant in exon 1 leading to the replacement of a glycine by an aspartic acid at codon 31 (p.Gly31Asp) was found in the proband from kindred RIB, but not in his diabetic son. A c.638T $>C$ variant in exon 3 , that results in the replacement of a isoleucine by a threonine at codon 213 (p.Ile213Thr) was observed in the proband from kindred TEM and in two other diabetic family members. The insertion of a cytosine at position c.872_873 in exon 4 resulting in a frameshift with a stop codon at position 24 of the new reading frame (p.Gly292Arg fsX24) was observed in the proband of kindred TRI. A deletion of two nucleotides at position c.1136_1137 (CT) in exon 6 leading to a frameshift with a stop codon at position 37 of the new reading frame (p. Pro379Arg fsX37) was observed in the proband of kindred GRU. Finally, a c. $1501+1 \mathrm{G}>\mathrm{T}$ replacement in the first base of the splice donor site of intron 7 was observed in the proband of kindred VIE.
Demographic and clinical profile of MODY3 subjects and subjects negative for MODY3 mutations are shown in Table 2. Except for a younger age at diagnosis in MODY3 subjects, no differences were observed between the two groups. All participants had negative antiGAD antibodies.

\section{DISCUSSION}

We have detected one variant in the glucokinase gene and six different variants in the HNFla gene in seven families of a panel of thirteen Brazilian kindred, with clinical diagnosis of MODY. It is unclear whether the glucokinase Gly 17Ser variant observed in the proband of family FER is a causal mutation. The variant was not observed in the proband's elder sister who had diabetes diagnosed at the age of 16 . Moreover, the proband is overweight and her sister is obese (BMI of 29.1 and $30.6 \mathrm{~kg} / \mathrm{m}^{2}$, respectively), which is uncommon in subjects with GCK-related diabetes. The glycine at position 117 is predicted to be potentially important for glucose phosphorylation, but both glycine and serine are neutral and polar aminoacids. In vitro studies are needed to assess the functional impact of this variant.

Table 2. Clinical and laboratory characteristics of MODY3 and MODY X patients.

\begin{tabular}{|c|c|c|c|}
\hline & $\begin{array}{l}\text { MODY } 3 \\
(\mathrm{~N}=10)\end{array}$ & $\begin{array}{l}\text { MODY X } \\
(N=06)\end{array}$ & $p$ \\
\hline Male/female & $2 / 8$ & $1 / 5$ & 0.69 \\
\hline Age at diagnosis (years) & $21 \pm 5$ & $32 \pm 13$ & 0.029 \\
\hline Body mass index $\left(\mathrm{kg} / \mathrm{m}^{2}\right)$ & $24 \pm 3$ & $24 \pm 4$ & 0.68 \\
\hline Male waist (cm) & $95 \pm 5$ & $102 \pm 6$ & 0.23 \\
\hline Female waist $(\mathrm{cm})$ & $84 \pm 8$ & $76 \pm 11$ & 0.22 \\
\hline Hypertension n (\%) & $2(20)$ & $2(33.3)$ & 0.49 \\
\hline Total Cholesterol (mg/dl) & $197 \pm 37$ & $195 \pm 61$ & 0.95 \\
\hline HDL Cholesterol (mg/dl) & $58 \pm 7.4$ & $51 \pm 22$ & 0.56 \\
\hline Triglycerides (mg/dl) & $81(41-130)$ & $93(56-580)$ & 0.35 \\
\hline $\mathrm{FPG}(\mathrm{mg} / \mathrm{dl})$ & $125 \pm 49$ & $152 \pm 71$ & 0.49 \\
\hline $\mathrm{HbAlc}(\%)$ & $7.06 \pm 1.6$ & $7.5 \pm 2.1$ & 0.67 \\
\hline Nephropathy n (\%) & $2(20.0)$ & $1(16.7)$ & 0.20 \\
\hline Neuropathy n (\%) & $1(10.0)$ & $1(16.7)$ & 0.64 \\
\hline Retinopathy n (\%) & $4(40.0)$ & $2(33.3)$ & 0.55 \\
\hline Heart disease n (\%) & $3(30.0)$ & $1(16.7)$ & 0.50 \\
\hline
\end{tabular}


The HNFla variants are likely to cause diabetes in the families where they were observed. The p.Ile213Thr cosegregates with diabetes in family TEM and is predicted to be deleterious to HNFIA function (Polyphen, SIFT, Panther and SNPs3D prediction models). The p.Gly31Asp observed in the proband from family RIB was not observed in her son who also had diabetes, but was previously found to cosegregate with diabetes in a French MODY family (5). The two frameshift mutations (p.Gly292Arg fsX24, p.Pro379Arg fsX37) generate truncated proteins that probably present severely impaired transcriptional activity. Moreover, the p.Gly292Arg fsX24 was previously found to cosegregate with diabetes in a MODY family from Scotland (12). The insertion in intron 7 (c.1501+lG>T) abolishes the splice donor site resulting almost certainly in the generation of abnormal transcripts. The duplication of four aminoacids in exon 1 (p.Gln9_Leul2dup) seems to cosegregate with diabetes in family MIL.

Mutations in the HNFl $\alpha$ gene are the most frequent cause of monogenic diabetes in adults. It was estimated that they may account for approximately $1 \%$ of cases of diabetes (13). More than 300 different mutations have been reported to date $(14,15)$. Studies in several populations (5-7,16-19), including two Brazilian studies $(17,19)$, have shown that GCK and HNFla mutations account to about half the cases of clinically defined MODY (familiar diabetes with early age of onset). When the autosomal dominant transmission can be clearly ascertained in families within three generations and the phenotype is strictly defined, the frequency of observed GCK and HNFl $\alpha$ mutations may be higher still $(5,7)$. Our findings are, therefore, in accordance with reported series. A recurrent question at the end of these studies, including ours, is regarding the etiology of diabetes in GCK, HNFl $\alpha, \mathrm{HNF} 4 \alpha$-negative cases. Possible explanations would include mutations in other unknown genes causing monogenic diabetes, combination of rare polymorphisms with a minor effect in known MODY genes, other molecular defects of GCK or HNFl $\alpha$ not detected by sequencing (20) and polygenic type 2 diabetes with early onset.

Making a diagnosis of MODY subtypes and other monogenic forms of diabetes is important for appropriate patient care, as well as being of scientific interest. Patients with GCK, HNFl $\alpha / \mathrm{HNF} 4 \alpha$ or HNF1B mutations have different clinical courses, regarding the progression of hyperglycemia, treatment requirements, complication risk and pregnancy outcome (1,9,14,21-24).
Recently, guidelines have been developed to suggest clinical criteria for the molecular testing of monogenic diabetes $(25,26)$. Thus, diabetes in the presence of extrapancreatic features such as renal cysts and genitourinary malformations points out to HNFIB mutations (9), and in the presence of deafness and pigmentary retinopathy suggest the mitochondrial m.3243A $>\mathrm{G}$ mutation (27). A mild and relatively stable chronic hyperglycemia that increases little after food or an oral glucose load, with very early age of onset (usually diagnosed at birth or in early childhood), without complications and for which treatment is rarely needed, strongly suggests a $G C K \mathrm{mu}$ tation (23). Testing for HNFla/HNF4 $\alpha$ mutations is recommended in patients with young-onset diabetes $(<25$ years in at least one family member), family history of diabetes in at least two generations, absence of pancreatic islet autoantibodies, glycosuria at blood glucose levels $<180 \mathrm{mg} / \mathrm{dl}$ (low renal threshold), marked sensitivity to sulfonylurea, and no marked obesity or evidence of insulin resistance.

In conclusion, we have confirmed in a South-Brazilian population that HNFla mutations are a common cause of monogenic diabetes in adults selected with strict clinical diagnostic criteria. HNFla mutations were identified in half of the patients with a family history of diabetes in three consecutive generations, in which at least one individual had diabetes diagnosed before the age of 25. Subjects with HNFla mutations had a diagnosis of diabetes at a younger age than subjects without mutations, but our study did not have the power to detect other clinical and biological differences between the two groups of subjects. It is now clear that there are differences in prognosis and treatment of the various forms of monogenic diabetes. They strongly support the use of molecular genetic testing for a precise diagnosis.

No potential conflict of interest relevant to this article was reported.

\section{REFERENCES}

1. Timsit J, Bellanné-Chantelot C, Dubois-Laforgue D, Velho G. Diagnosis and management of maturity-onset diabetes of the young. Treat Endocrinol. 2005;4:9-18.

2. Giuffrida FM, Reis AF. Genetic and clinical characteristics of maturity-onset diabetes of the young. Diabetes Obes Metab. 2005;7:318-26.

3. Campagnolo N, Dallapicola PF, Murussi N, Canani LH, Gross JL, Silveiro SP. Aspectos clínicos e moleculares do Maturity Onset Diabetes of the Young (MODY). Revista do Hospital de Clínicas de Porto Alegre. 2005;24:51-9. 
4. Molven A, Ringdal M, Nordbo AM, Raeder H, Stoy J, Lipkind GM, et al. Mutations in the insulin gene can cause MODY and autoantibody-negative type 1 diabetes. Diabetes. 2008;57:1131-5.

5. Chèvre JC, Hani EH, Boutin $P$, Vaxillaire $M$, Blanché $H$, Vionnet $\mathrm{N}$ et al. Mutation screening in 18 caucasian families suggests the existence of other MODY genes. Diabetologia. 1998;41: 1017-23.

6. Costa A, Bescós M, Velho G, Chêvre JC, Vidal J, Sesmilo G, et al. Genetic and clinical characterisation of MODY in Spanish families. Eur J Endocrinol. 2000;142:380-6.

7. Frayling TM, Bulamn MP, Ellard S, Appleton M, Dronsfield MJ, Mackie AD, et al. AT Mutations in the hepatocyte nuclear factor-1alpha gene are a common cause of maturity-onset diabetes of the young in the U.K. Diabetes. 1997;46:720-5.

8. Pearson ER, Pruhova S, Tack CJ, Johansen A, Castleden HA, Lumb PJ, et al. Molecular genetics and phenotypic characteristics of MODY caused by hepatocyte nuclear factor 4alpha mutations in a large European collection. Diabetologia. 2005; 48:878-85.

9. Bellanné-Chantelot C, Chauveau D, Gautier JF, Dubois-Laforgue D, Clauin S, Beaufils $S$, et al. Clinical spectrum associated with hepatocyte nuclear factor-1beta mutations. Ann Intern Med. 2004;140:510-7.

10. Edghill EL, Bingham C, Ellard S, Hattersley AT. Mutations in hepatocyte nuclear factor-1 beta and their related phenotypes. J Med Genet. 2006;43:84-90.

11. Bingley PJ, Bonifacio E, Mueller PW. Diabetes Antibody Standardization Program: first assay proficiency evaluation. Diabetes. 2003; 52:1128-36.

12. Yamagata K, Oda N, Kaisaki PJ, Menzel S, Furuta H, Vaxillaire $\mathrm{M}$, et al. Mutations in the hepatocyte nuclear factor 1 alpha gene in maturity-onset diabetes of the young (MODY3). Nature. 1996;384:455-8.

13. Hattersley AT. Maturity-onset diabetes of the young: clinical heterogeneity explained by genetic heterogeneity. Diabet Med. 1998;15:15-24.

14. Bellanne-Chantelot C, Carette $C$, Riveline JP, Valero R, Gautier $\mathrm{JF}$, Larger E, et al. The type and the position of HNF1A mutation modulate age at diagnosis of diabetes in patients with maturity-onset diabetes of the young (MODY)-3. Diabetes. 2008;57:503-8.

15. Ellard S, Colclough K. Mutations in the genes encoding the transcription factors hepatocyte nuclear factor 1 alpha $(H N$ F1A) and 4 alpha (HNF4A) in maturity-onset diabetes of the young. Hum Mutat. 2006;27:854-69.

16. Lindner TH, Cockburn BN, Bell GI. Molecular genetics of MODY in Germany. Diabetologia. 1999;42:121-3.

17. Moisés RS, Reis AF, Morel V, Chacra AR, Dib SA, BellannéChantelot C, Velho G. Prevalence of MODY mutations in Brazil- ian families with autosomal dominant early-onset type 2 diabetes mellitus. Diabetes Care. 2001;24:786-8.

18. Johansen A, Ek J, Mortensen HB, Pedersen O, Hansen T. Half of clinically defined maturity-onset diabetes of the young patients in Denmark do not have mutations in HNF4A, GCK, and TCF1. J Clin Endocrinol Metab. 2005;90:4607-14.

19. Furuzawa GK, Giuffrida FM, Oliveira CS, Chacra AR, Dib SA, Reis AF. Low prevalence of MODY2 and MODY3 mutations in Brazilian individuals with clinical MODY phenotype. Diabetes Res Clin Pract. 2008;81:e12-14.

20. Ellard S, Thomas K, Edghill EL, Owens M, Ambye L, Cropper J, et al. Partial and whole gene deletion mutations of the GCK and HNF1A genes in maturity-onset diabetes of the young. Diabetologia. 2007;50:2313-7.

21. Fajans SS, Bell GI, Polonsky KS. Molecular mechanisms and clinical pathophysiology of maturity-onset diabetes of the young. N Engl J Med. 2001;345:971-80.

22. Pearson ER, Starkey BJ, Powell RJ, Gribble FM, Clark PM, Hattersley AT. Genetic cause of hyperglycaemia and response to treatment in diabetes. Lancet.2003; 362:1275-81.

23. Velho G, Froguel P, Gloyn A, Hattersley AT. Maturity onset diabetes of the young type 2. In: Magnuson M, Matschinsky F, editors. Glucokinase and Glycemic Diseases: from the Basics to Novel Therapeutics. Basel, Karger. 2004, p. 42-64.

24. Martin D, Bellanné-Chantelot $C$, Deschamp I, Froguel P, Robert JJ, Velho G. Long-term follow-up of OGTT-derived glucose tolerance, insulin secretion and insulin sensitivity indices in subjects with glucokinase mutations (MODY2). Diabetes Care. 2008;31:1321-3.

25. Ellard S, Bellanne-Chantelot C, Hattersley AT. Best practice guidelines for the molecular genetic diagnosis of maturityonset diabetes of the young. Diabetologia. 2008;51:546-53.

26. Murphy R, Ellard S, Hattersley AT. Clinical implications of a molecular genetic classification of monogenic beta-cell diabetes. Nat Clin Pract Endocrinol Metab. 2008;4:200-13.

27. Guillausseau PJ, Massin P, Dubois-LaForgue D, Timsit J, Virally $M$, Gin $H$, et al. Maternally inherited diabetes and deafness: a multicenter study. Ann Intern Med. 2001;134:721-8.

\section{Correspondence to:}

Sandra Pinho Silveiro

Endocrine Division, Hospital de Clínicas de Porto Alegre UFRGS

Rua Ramiro Barcelos, 2350 - 4 andar, Prédio 12

90035-903 Porto Alegre RS

E-mail: sandrasilveiro@terra.com.br 